\title{
Peningkatan Menulis Teks Fantasi Menggunakan Metode PJBL Berbantuan Media Bontang
}

\author{
Improvement on Writing Fantasy Text using the Project-Based Learning Method in \\ Assistance with Hand Puppet Media \\ ${ }^{1 *}$ Monika Priastari, ${ }^{2)}$ Wika Soviana Devi \\ Universitas Muhammadiyah Jakarta \\ *email: monikapriastari06@gmail.com,wikasoviana@umj.ac.id
}

\begin{abstract}
Histori Artikel:
ABSTRAK

Diajukan:

07/04/2021

Diterima:

09/07/2021

Diterbitkan:

$13 / 07 / 2021$

Penelitian ini bertujuan untuk mengetahui adanya peningkatan keterampilan menulis teks cerita fantasi dari penggunaan metode pembelajaran berbasis proyek (PJBL) berbantuan media Bontang (Boneka tangan) di kelas VII SMP Terpadu Darussalam Depok. Jenis penelitian adalah penelitian saintifik dengan pendekatan penelitian tindakan kelas yang dimana saat eksperimennya menggunakan 3 tahapan prasiklus, siklus I, dan siklus II. Penelitian dilaksanakan di kelas VII-A pada semester ganjil tahun 2020/2021 dengan subjek penelitian berjumlah 20 peserta didik. Hasil penelitian ini menunjukkan kemampuan menulis cerita fantasi siswa kelas VII-A SMP Terpadu Darussalam Depok mengalami peningkatan di setiap siklusnya. Nilai rata-rata pembelajaran menulis cerita fantasi prasiklus 53 siklus I sebesar 73,5 dan siklus II 79,5. Dengan demikian dapat dibuktikan bahwa penggunaan metode Pembelajaran Berbasis Proyek berbantuan media Bontang (boneka tangan) dapat dijadikan alternatif dalam pembelajaran menulis cerita fantasi, dan dapat meningkatkan kemampuan menulis cerita fantasi siswa kelas VII-A SMP Terpadu Darussalam Depok.
\end{abstract}

Kata kunci: Keterampilan Menulis; Cerita Fantasi; PTK; Metode PJBL; Media Bontang

\begin{abstract}
This study aims to determine an increase in the skills of writing fantacy story texts from the use of project-based leasrning (PJBL) methods assisted by Bontang media (hand puppets) in class VII SMP Terpadu Darussalam Depok, 3 stages of pre-cycle, cycle I, and cycle II. The research was conducted in class VII-A in the odd semester of 2020/2021 eith 20 students as reseach subjects. The results of this study showed that the ability to write fantacy stories of class VII-A students of SMP Terpadu Darussalam Depok had increased in each cycle. The average value of learning to write fantasy stories pre-cycle 53 in the first cycle was 73,5 and the second cycle was 79,5. Thus it can be proven that the use of the Project-Based Learning (PJBL) method assisted by Bontang media (hand puppets) can be used as an alternative in learning to write fantasy stories, and can improve the ability to write fantasy stories of class VII-A students of SMP Terpadu Darussalm Depok.
\end{abstract}

Keywords: Writing Skills; Fantasy Stories; Car; PJBL Methods; Bontang

\section{PENDAHULUAN}

Menulis merupakan kegiatan yang menuntut dari beberapa proses yang di antaranya pra penulisan atau persiapan, membuat draf, revisi, barulah terakhir tahap editing untuk menghasilkan tulisan yang baik dan benar. Dalam menulis diperlukan pengetahuan, pemahaman, dan pengalaman 
yang mengiringi keterampilannya (Fadly 2020: 305). Di antara empat keterampilan berbahasa, menulis berada di urutan terakhir. Maksudnya, untuk memperoleh keterampilan menulis seseorang harus melalui keterampilan menyimak, berbicara, dan keterampilan membaca. Namun, pembelajarannya dapat dimulai sejak seseorang mampu membaca. karena membaca dan menulis merupakan perpaduan keterampilan reseptif dan produktif sehingga apa yang dibaca dapat menjadi bahan atas apa yang ditulis (Rahmalemna, 2015:23). Saddhono (2012: 96) memaparkan bahwa menulis ialah kegiatan menggali pikiran dan perasaan suatu objek, memilih suatu hal yang akan ditulis, menentukan bagaimana cara menuliskannya agar pembaca mudah dan jelas dalam memahaminya.

Dalman (2014: 7) dalam menulis terdapat beberapa proses yang diantaranya: tahap prapenulisan, penulisan, dan paska penulisan. Pada fase prapenulisan yaitu menentukan topik, tujuan, dan sasaran karangan untuk mengumpulkan bahan lalu disusun menjadi kerangka karangan. Lalu fase penulisan, fase terusan dari kerangka karangan yang disusun dari butir karangan sampai membentuk sebuah paragraf. Selanjutnya setelah paragraf-paragraf tadi membentuk sebuah karangan utuh, selanjutnya dilakukan proses penyuntingan yang dilakukan secara berulang sebagai perbaikan agar karangan yang ditulis dapat sesuai dengan apa maksud yang ingin disampaikan.

Menulis adalah proses penyampaian pikiran, imajinasi, serta perasaan hati seseorang ke tulisan yang memiliki makna. Dalam menulis, seseorang berusaha mengilustrasikan pikirannya dan dituangkan lewat kata yang dikaitkan menjadi kalimat, paragraf sampai antar bab supaya pembaca mudah memahami. Kegiatan menulis merupakan suatu kegiatan yang harus selalu dilatih secara terus menerus dan merupakan pembiasaan yang harus ditekuni sejak dini. Menulis bagaikan sebuah karya seni kriya yang bilamana dilatih, secara terus menerus maka akan dengan mudah mengolah setiap katakata, makna, nilai bahasa, sampai sudut pandang.
Istilah membaca itu tentu tidak terbatas pada objek tulisan, melainkan juga pada objek nonlingual seperti benda, orang, dan suasana lingkungan. Dari berbagai objek yang dilihat seseorang dapat membaca dan menyimpannya dalam imaji mengembangkannya dan dituliskan dalam bentuk teks cerita fantasi. Menurut Yanner, dkk. (2018: 101) cerita fantasi adalah sebuah cerita yang di dalamnya mengandung keajaiban dari pemunculan tokoh yang unik seperti robot, pohon, ataupun benda mati tetapi dapat berbicara bahkan memiliki perilaku layaknya manusia. cerita fantasi ialah sebuah karangan tulisan bersifat khayalan atau imajinasi penulis yang menceritakan serta menggambarkan dengan jelas pengalaman, adegan demi adegan secara imajinasi, impian atau praduga belaka. Dapat diartikan bahwa teks fantasi merupakan sesuatu keadaan yang bersifat tidak dapat dicari keasliannya dalam dunia nyata. Perilaku dan sikap tokoh yang tidak mungkin menjadi mungkin, dan latar dapat menembus ruang dan waktu dimensi lain. Tema yang terdapat di dalam teks cerita fantasi biasanya seperti supranatural, majis dan juga futuristik.

Pembelajaran menulis teks cerita fantasi dapat mulai diajarkan pada kelas VII Sekolah Menengah Pertama (SMP) disemester gasal berdasarkan Kurikulum 2013. Dari pembelajaran tingkat awal tahap SMP, pembelajaran tersebut tentu diperlukannya penanganan yang tepat. Sebab, pada tahap tersebut menjadi fondasi pada pembelajaran menulis berikutnya. Meskipun demikian, siswa-siswi kelas VII yang umumnya berada pada rentang usia 13-14 tahun menempatkan mereka pada masa remaja tahap awal. Teks cerita fantasi sangat sesuai dengan karakteristik umum peserta didik SMP yang masuk kategori kepada usia belajar dan masa transisi. Dimana saat usia ini mereka sangat gemar akan sesuatu yang fantastis walaupun sekadar fiktif dan imajinatif. Kegemaran tersebut dapat dituangkan dalam bentuk literasi untuk membangun produktivitas diri yang berupa menulis teks cerita fantasi. Masa remaja awal merupakan sebuah masa peralihan perkembangan dan pertumbuhan akibat semua perubahan fisik, sosial, dan emosional 
sehingga dapat menimbulkan rasa cemas dan ketidaknyamanan. Tentu hal tersebut menjadi tantangan dalam pembelajaran, termasuk menulis teks cerita fantasi.

Pembelajaran menulis teks cerita fantasi menuntut konsentrasi yang tinggi agar siswa dapat mengeksplor imajinasi untuk dituangkan ke dalam kerangka tulisan, selanjutnya dikembangkan menjadi tulisan yang utuh. Meskipun demikian, dalam menciptakan suasana yang kondusif di kelas VII-A SMP Terpadu Darussalam Depok perlu solusi yang tepat. Di tinjau saat observasi, kolabolator menuturkan banyak peserta didik yang sukar dalam mengutarakan kata-kata, mengolah apa yang ada dalam pikiran menjadi bahasa tulisan yang apik. Terlebih peserta didik mengalami kesulitan dalam mencari ide utama untuk menulis karena asik bermain dengan dunianya sendiri, sehingga ketika ditugaskan membuat karangan cerita fantasi. Hal tersebut dapat terjadi karena rendahnya tingkat minat baca peserta didik yang berpotensi kepada penguasaan kosakatanya juga menurun, serta kurangnya motivasi belajar peserta didik itu sendiri.

Menurut Mukrimaa (2014: 45) cara atau prosedur yang dipergunakan oleh fasilitator dalam interaksi belajar dengan memperhatikan keseluruhan sistem untuk mencapai suatu tujuan. Menurut Helmiati (2012: 57) metode pembelajaran merupakan prosedur, urutan, langkah-langkah, serta cara yang guru dalam mencapai tujuan pembelajaran. Dalam memberikan suatu bahan ajar guru harus memperhatikan metode dan strategi pembelajaran agar peserta didik dapat belajar secara konkret. Guru harus dapat menguasai keadaan suatu kelas sehingga akan tercipta suasana yang menyenangkan bagi peserta didik-peserta didiknya dan nantinya akan menghasilkan proses pembelajaran yang berkualitas. Maka dapat disimpulkan bahwa metode pembelajaran adalah langkah atau pedoman pembelajaran yang diterapkan guru, untuk menunjang aktivitas belajar mengajar di dalam kelas berjalan dengan baik.

Sesuai dengan tantangan pada kelas VIIA SMP Terpadu Darussalam Depok peneliti ini menggunakan metode pembelajaran berbasis proyek berbantuan media Bontang
(Boneka Tangan) yang mampu menarik perhatian dan konsentrasi siswa ke satu fokus. Marliana, dkk (2018: 71) mengutarakan bahwa metode pembelajaran berbasis proyek merupakan sebuah metode yang menggunakan proyek/ kegiatan sebagai medianya. Arizona dalam Abidin (2020: 65) pembelajaran berbasis proyek adalah penelusuran mendalam tentang sebuah topik dari dunia nyata. Menurut Sahin dalam Abidin (2020: 67) Secara khusus, pembelajaran berbasis proyek terdiri dari tugas-tugas berbasis penyelidikan yang membantu peserta didik mengembangkan pentingnya teknologi, sosial, dan inti dari kurikulum. Metode pembelajaran yang menggunakan langkah awal dalam mengumpulkan dan mengintegrasikan pengetahuan baru berdasarkan pengalamannya dalam beraktivitas secara nyata.

Dalam pembelajaran ini, permasalahan yang ingin dikemukakan sangat kompleks. Berlandaskan pemaparan sebelumnya bahwa pembelajaran berbasis proyek yaitu penyelesaian masalah yang mendalam melalui penyelidikan, serta menghasilkan sebuah produk. Metode pembelajaran berbasis proyek dipilih peneliti karena sesuai dengan keadaan dimasa Pandemi seperti ini, melalui sistem metode yang berpusat kepada produk diakhir pembelajarannya berupa teks cerita fantasi siswa. Media Bontang (Boneka Tangan) dipilih peneliti agar siswa dapat lebih fokus dalam berimajinasi untuk mencipta cerita fantasi yang lebih baik dan benar lagi. Miarso dalam Indriyani (2019: 3) media pembelajaran merupakan sesuatu yang digunakan untuk menyalurkan pesan yang dapat merangsang pikiran, perasaan, perhatian dan kemauan siswa unruk belajar agar mencapai tujuan.

Gunarti dalam Sulianto, dkk. (2014: 95) boneka yang ukurannya lebih besar dari boneka jari dan dimainkan dengan memasukannya ke tangan disebut boneka tangan. Sementara menurut Sudjana dan Rivai (2019: 188) boneka yang digerakkan melalui tangan seseorang ke dalam baju boneka disebut boneka tangan. Adapun media yang digunakan dalam penelitian ini ialah media boneka tangan yang bebentuk karakter dari tema "Corona". Dipilihnya media tersebut untuk membantu siswa dalam memunculkan 
imajinasi membuat cerita fantasi. Metode penelitian yang diterapkan dalam penelitian ini ialah penelitian tindakan kelas (PTK). Sebagai upaya refleksi diri, PTK bertujuan untuk memperbaiki kinerja peneliti yang sekaligus sebagai pendidik sehingga hasil belajar menulis teks deskripsi meningkat. Di dalam penelitian ini, peneliti menggunakan model dari Stephen Kemmis dan Robbert Mc Taggart. Dimana dalam penelitian tindakan kelas ini terdapat empat tahapan, diantaranya; perencanaan tindakan, pelaksanaan tindakan, pengamatan atau observasi, dan terakhir refleksi atau pantulan dari beberapa tahap yang dilakukan. Menurut Soesatyo, dkk (2017: 165) penelitian PTK model S. Kemmis dan Mc Taggart merupakan pengembangan Kurt Lewin yang hanya saja dalam komponen acting dan observing dijadikan satu kesatuan karena tidak dapat dipisahkan dalam satu waktu yang sama. Pada penelitian ini, peneliti bekerja sama dengan kolaborator, yaitu guru mata pelajaran bahasa Indonesia Ibu Wida Widyaningsih, S.Pd. Prosedur penelitian tindakan kelas ini menggunakan dua siklus dengan dua pertemuan pada setiap siklusnya. Prosedur tindakan yang dilakukan oleh peneliti meliputi prasiklus (mengidentifikasi masalah, mendiskusikannya, dan mencari solusi bersama kolaborator) dan tindakan (menyusun rencana kegiatan harian, menerapkannya, mengobservasi, dan melakukan refleksi).

Selain memanfaatkan data kualitatif berupa observasi, penelitian ini juga menggunakan data kuantitatif berupa hasil belajar siswa yang dikonversi dari hasil produk menulis cerita fantasi.

Peningkatan hasil belajar terlihat dengan membandingkan skor prasiklus dan siklus II. Skor maksimal yang diperoleh siswa adalah 100 , sedangkan rata-rata dihitung dengan rumus jumlah skor keseluruhan dibagi jumlah siswa.

$\mathrm{X} \frac{£ \mathrm{x}}{N}$

$\mathrm{X} \quad$ : Nilai Rata-rata

$\sum \mathrm{x} \quad$ : Jumlah semua nilai

$N \quad$ : Seluruh peserta didik

$100 \%$ : Bilangan tetap.

\section{METODE}

Metode penelitian yang peneliti gunakan adalah metode penelitian tindakan kelas dengan pendekatan pembelajaran saintifik dimana saat melakukan penelitian terdapat tiga tahapan yaitu prasiklus, siklus I, dan siklus II. Setiap tahap terdapat empat komponen diantaranya perencanaan, pelaksanaa, pengamatan, dan terakhir refleksi tetapi antara pengamatan dan refleksi dilakukan secara bersamaan sesuai dengan model penelitian PTK yang dipilih peneliti yaitu menurut Stephen Kemmis dan Robbert Mc Taggart. Variabel bebas dalam penelitian tindakan kelas ini adalah metode pembelajaran berbasis proyek yang akan diuji cobakan sebagai variabel $\left(\mathrm{X}_{1}\right)$ dan media pembelajaran Bontang (boneka tangan) sebagai variabel $\left(\mathrm{X}_{2}\right)$, dan variabel terikat adalah kemampuan menulis teks cerita fantasi peserta didik kelas VII-A SMP Terpadu Darussalam Depok tahun ajaran 2020/2021 sebagai variabel (Y).

Penelitian ini dilaksanakan di SMP Terpadu Darussalam Depok khususnya di kelas VII-A dengan jumlah peserta didik 20 peserta didik. Desain penelitian yang ditetapkan peneliti yaitu penggunaan PTK model S. Kemmis dan Mc. Taggart. Berikut gambaran dari desain penelitian.

Gambar 1.1 Rangkaian PTK jenis S. Kemmis Dan R. Mc Taggart

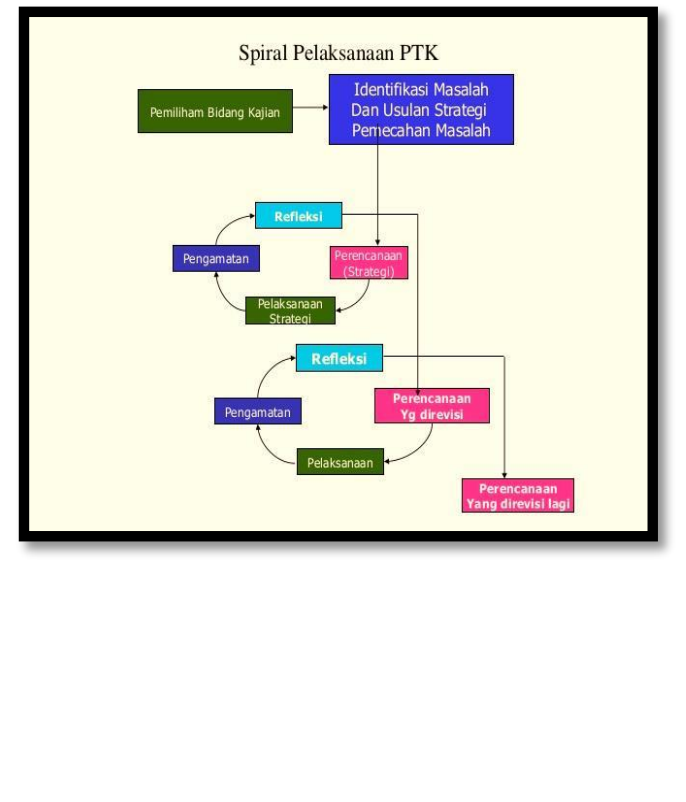




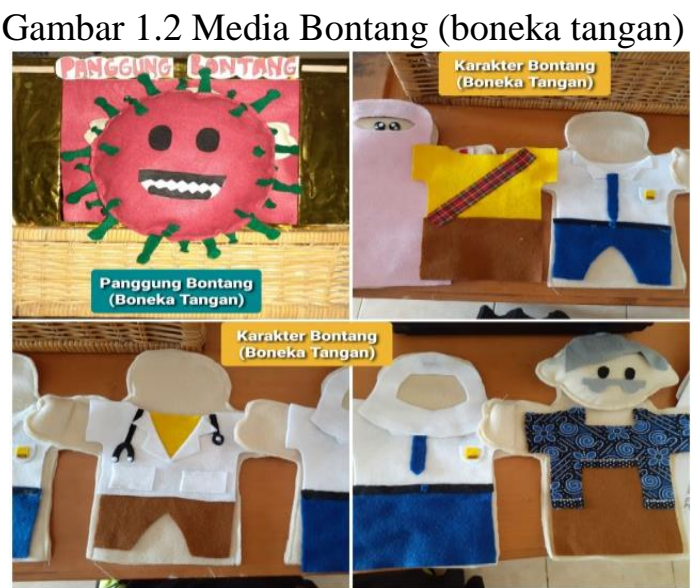

Pada penelitian ini penulis akan melakukan penelitian di kelas VII-A SMP Terpadu Darussalam Depok sesuai dengan prosedur penelitian yang telah dirancang, namun perubahan pola pembelajaran yang saat ini terjadi akibat pandemi Covid-19 di Indonesia, yang berdampak kepada masifnya kegiatan pembelajaran disekolah di semua jenjang. Maka dari itu peneliti menggunakan penelitian dalam bentuk daring (dalam jaringan) untuk mensiasati keadaan yang terjadi.

Kagerman et al. dalam Abidin, dkk (2020: 65), dimana Revolusi Industri 4.0 lahir di Negara Jerman pada Tahun 2011 yang menyentuh dunia virtual, berbentuk konektivitas manusia melalui mesin, perangkat, sensor dan data yang lebih dikenal dengan nama Internet of Things (IoT). Sesuai dengan revolusi Industri 4.0 dimana industri pada abad ke-21 mengalami perubahan besarbesaran di berbagai bidang lewat perpaduan teknologi yang mengurangi komunikasi antar fisik, digital, dan biologi. Menurut Abidin, dkk (2020: 65) adanya digitalisasi sistem menuntut para pendidik dan peserta didik untuk mampu dengan cepat beradaptasi dengan perubahan yang ada.

Dalam penelitian ini penulis menggunakan alat bantu aplikasi Zoom Cloud Meetings yang berbentuk daring (dalam jaringan) sebagai perantara untuk menjelaskan konsep penelitian dari Bontang (Boneka Tangan) yang digunakan dalam pembelajaran keterampilan menulis teks cerita fantasi melalui video conference.
Sistematika yang direncakan peneliti yaitu menyiapkan kelompok belajar yang dibuat dari forum digital (whatsapp) tadi sesuai kesepakan bersama sekaligus untuk kegiatan diskusi peserta didik dalam mebuat proyek. Sementara penggunaan media Bontang (Boneka Tangan), karena tidak berbentuk digital maka penelitilah yang akan menggantikan peran peserta didik dalam mendemonstrasikan mulai dari contoh penggunaan media sampai fungsi dari media yang diterapkan. Sesuai penjabaran pelaksanaan tindakan bahwa penelitian ini akan dilakukan dalam dua siklus, bilamana siklus pertama belum menunjukkan hasil yang sesuai maka akan dilanjutkan kepada siklus kedua, dan peneliti sangat berharap metode pelaksanaan penelitian melalui daring (dalam jaringan) ini dapat berjalan sesuai harapan tanpa terkendala permasalahan yang rumit.

Dibawah ini adalah bagan kerangka berpikir penelitian pengaruh penggunaan boneka tangan terhadap keterampilan menulis teks cerita fantasi siswa kelas VII-A SMP Terpadu Darussalam Depok.

\section{HIPOTESIS PENELITIAN}

Berdasarkan kerangka berpikir di atas, hipotesis dalam penelitian ini adalah :

$\mathrm{H}_{\mathrm{o}}$ : Penggunaan metode pembelajaran berbasis proyek (PJBL) berbantuan media Bontang (boneka tangan) tidak berpengaruh terhadap keterampilan menulis teks cerita fantasi peserta didik kelas VII-A SMP Terpadu Darussalam Depok

$\mathrm{H}_{1}$ : Penggunaan metode pembelajaran berbasis proyek (PJBL) berbantuan media Bontang (boneka tangan) berpengaruh terhadap keterampilan menulis teks cerita fantasi peserta didik kelas VII-A SMP Terpadu Darussalam Depok.

\section{HASIL DAN PEMBAHASAN}

Atas dasar observasi pada 28 Agustus 2020, penelitian ini menghasilkan analisis data pada tahap prasiklus sebagai berikut: 


\section{A. Prasiklus}

Tahap ini dilalui oleh peneliti dengan menyusun perencanaan berupa penyiapan rencana kegiatan harian atau rencana pelaksanaan pembelajaran (RPP) sebagai pedoman pelaksanaan pembelajaran dengan menggunakan film. Selain itu, peneliti ini mempersiapkan dan memastikan berfungsinya infokus di dalam kelas. Lembar penilaian, lembar pengamatan siswa, lembar pengamatan aktivitas guru, dan kamera juga disiapkan sebagai alat dokumentasi.

Dalam perencanaan ini, peneliti mempersiapkan materi teks cerita fantasi beserta contoh singkatnya untuk dijelaskan dalam metode biasa yaitu ceramah yang dikemas dalam video singkat dan diunggah ke google classroom. Selain itu peneliti juga mempersiapkan beberapa lembar instrumen penugasan/tes berikut lembar penilaian menulis teks cerita fantasi, serta lembar pengamatan aktivitas guru yang diisi oleh kolabolator.

$$
\begin{array}{r}
\text { Rata-rata }=\frac{\text { jumlah nilai }}{\text { jumlah siswa }} \\
=\frac{1060}{20}=53
\end{array}
$$

Pada tahap refleksi menunjukkan hasil prasiklus pada pembelajaran keterampilan menulis dengan jumlah peserta didik sebanyak 20 peserta didik. Nilai KKM yang harus dicapai oleh peserta didik untuk mata pelajaran bahasa Indonesia adalah 70, dari hasil penilaian prasiklus terdapat 1 peserta didik yang sudah tuntas dari KKM dengan presentase 5\%, 19 peserta didik belum tuntas dari KKM dengan presentase $95 \%$, dan ratarata nilai prasiklus 53. Tentunya hasil dari dilakukannya prasiklus sangat jauh dari ketetapan KKM yaitu 70.

\section{B. Siklus I}

Pada siklus I ini dibuat dengan segala perbaikan dari tahap Prasiklus. Tindakan yang dilakukan yaitu dengan penerapan metode berbasis proyek dalam proses pembelajaran menulis cerita fantasi yang dimana peserta didik nanti akan menghasilkan sebuah produk yaitu teks cerita fantasi yang dibantu dengan katakter media boneka tangan. Dalam
Rencana Pelaksanaan Pembelajaran (RPP) di Siklus I peneliti membuat rancangan dengan tahapan awal menyiapkan metode berbasis proyek dengan cara kerja peserta didik dibagi menjadi 3 kelompok besar dan menyiapkan 5 karakter dari media boneka tangan. Dengan pemanfaatan media tersebut serta metode pembelajaran yang didahului dari kelompok kecil, diharapkan dapat meningkatkan motivasi belajar peserta didik dan tingkat rasa percaya diri peserta didik.

Peneliti melakukan penelitian dengan menggunakan media zoom cloud meeting untuk memotivasi peserta didik, ternyata antusiame peserta didik dalam mengikuti pembelajaran melalui video confrence lebih baik dibanding whatsapp. Walaupun memang hanya sebagian yang bergabung, setidaknya sudah $50 \%$ dari total semua peserta didik. Selama pembelajaran berlangsung peneliti juga memantau absensi yang dilakukan di media whatsapp. RPP di Siklus I ini dilakukan dalam 3 kali pertemuan tetapi untuk melakukan penelitian pada tahap tindakan peneliti jatuh pada tanggal 11 September pukul 09.00-10.00 WIB peneliti juga menyiapkan media boneka tangan untuk metode pembelajaran berbasis proyek dimana saat video confrence berlangsung peserta didik dibagi menjadi 3 kelompok kecil dan diberi penjelasan bahwa dalam pembelajaran kali ini peserta didik diharapkan mampu menghasilkan sebuah produk menulis cerita fantasi yang sesuai dengan struktur dan kaidah teks cerita fantasi.

Dengan cara kerja kelompok yang diketuai oleh satu orang untuk membantu pengumpulan tugas menulis cerita fantasi. Jadi ketua kelompok yang bertanggung jawab mengakomodir setiap kelompok kecilnya, dengan adanya pembelajaran dalam kelompok kecil tersebut diharapkan peserta didik dapat semakin percaya diri satu sama lain, menambah motivasi belajarnya, dan semakin bersemangat untuk menyelesaikan tugas yang diberikan oleh peneliti.

Pada tahap ini peneliti melakukan refleksi serta mengacu pada hasil temuan saat dilaksanakannya tindakan kelas. Setelah dilakukan analisis tersebut, peneliti mempertimbangkan rencana segala perbaikannya 
sebagai tindak lanjut untuk langkah pada Siklus II.

Rata-rata $=\frac{\text { jumlah nilai }}{\text { jumlah siswa }}$

$$
=\frac{1.470}{20}=73,5
$$

Hasil penelitian Siklus I diatas, menunjukkan nilai tuntas terdapat di 12 peserta didik dan nilai belum tuntas terdapat di 8 peserta didik. Dari data tersebut didapat bahwa nilai terendah pada siklus I adalah 67,5 dan nilai tertinggi adalah 82,5. Sedangkan rata-rata yang diperoleh adalah 73.5. Dari hasil siklus I menulis teks cerita fantasi dengan metode pembelajaran berbasis proyek (PJBL) berbantuan media Bontang (Boneka Tangan) diatas, peserta didik kelas VII-A termasuk ke dalam kategori meningkat dari hasil data prasiklus.

Berdasarkan hasil pengamatan Siklus I dapat diketahui bahwa pada saat pembelajaran menulis teks cerita fantasi dengan menggunakan metode berbasis proyek dan media boneka tangan tersebut sudah dapat mencapai KKM yang diharapkan, akan tetapi nilai tersebut masih kurang memuaskan karena terdapat beberapa peserta didik yang mendapat nilai rendah. Maka dari itu, peneliti merasa masih harus melakukan tindakan lanjut dengan menggunakan metode pembelajaran berbasis proyek berbantuan media boneka tangan untuk pembelajaran pertemuan sebelumnya guna memperoleh hasil yang lebih baik dan meningkat.

\section{Siklus II}

Peneliti menyusun RPP sama seperti di siklus I mengenai teks cerita fantasi dengan menerapkan metode pembelajaran berbasis proyek (PJBL), RPP pada siklus II dirancang sama untuk 3 kali pertemuan, dimana tahap tindakan dilakukan pada tanggal 3 September 2020. RPP siklus II ini merupakan cerminan dari siklus I. Dalam siklus II peneliti menggunakan media sama yaitu whatsapp, google classroom dan media zoom cloud meeting. Diberlakukannya media tambahan tersebut untuk mempermudah akses atau proses pembelajaran yang akan dilakukan. Sama seperti pertemuan prasiklus dan siklus I di siklus II ini, peneliti membuka pembelajaran dengan media whatsapp sebagai sarana untuk mengisi absensi kehadiran peserta didik. Selanjutnya peneliti mengingatkan kembali bahwa pembelajaran pada tanggal 3 September 2020 akan menggunakan media zoom cloud meeting, maka peneliti pun segera mengirimkan ID zoom ke group whatsapp. Setelah dirasa sudah $50 \%$ hadir di media zoom cloud meeting selanjutnya peneliti memberikan apresiasi terhadap hasil menulis atau produk menulis teks cerita fantasi di pertemuan sebelumnya. Sesuai kesepakatan yang sudah ditetapkan, bahwa kelompok yang lebih cepat mengumpulkan hasil tulisannya akan mendapat hadiah sebagai motivasi tambahan untuk meningkatkan semangat belajar.

$$
\begin{aligned}
\text { Rata-rata } & =\frac{\text { jumlah nilai }}{\text { jumlah siswa }} \\
& =\frac{1560}{20}=78
\end{aligned}
$$

Dari data tersebut didapat bahwa nilai terendah pada siklus II adalah 75 dan nilai tertinggi adalah 85 . Sedangkan rata-rata yang diperoleh adalah 78. Dari hasil siklus II menulis teks cerita fantasi dengan metode pembelajaran berbasis proyek (PJBL) berbantuan media Bontang (Boneka Tangan) diatas, peserta didik kelas VII-A termasuk ke dalam kategori meningkat dari hasil data prasiklus yang belum diberlakukannya metode pembelajaran berbasis proyek (PJBL) dan media Bontang (Boneka Tangan) ataupun siklus sebelumnya yaitu siklus II yang sudah diterapkannya metode pembelajaran bebasis proyek PJBL dan media Bontang (Boneka Tangan). Penerapan metode pembelajaran berbasis proyek (PJBL) berbantuan media Bontang (Boneka Tangan) di materi teks cerita fantasi telah menunjukkan keberhasilan dari meningkatnya hasil menulis peserta didik dari prasiklus, ke tahap siklus I, dan tahap siklus II.

Nilai yang diperoleh peserta didik dari nilai terendah hingga nilai tertinggi dapat dilihat dari tabel berikut ini. 
Monika Priastari, Wika Soviana Devi

Peningkatan Menulis Teks Fantasi Menggunakan Metode PJBL Berbantuan Media Bontang

Tabel 1.1

Tingkat Keterampilan Menulis Cerita Fantasi

\begin{tabular}{|l|l|l|l|l|}
\hline No & Nama & $\begin{array}{l}\text { Pra } \\
\text { Siklus }\end{array}$ & Siklus I & Siklus II \\
\hline 1. & Terendah & 45 & 67,5 & 75 \\
\hline 2. & Tertinggi & 75 & 82,5 & 85 \\
\hline $\begin{array}{l}\text { Rata- } \\
\text { Rata }\end{array}$ & 53 & 73,5 & 78 \\
\hline
\end{tabular}

\section{KESIMPULAN}

Permasalahan atau hambatan dalam pembelajaran cerita fantasi pada kelas VII SMP Terpadu Darussalam Depok dapat diatasi dengan penggunaan media yang tepat. Media Bontang dapat menjadi alternatif dalam mengatasi permasalahan kurang fokusnya daya imajinasi dalam menghadirkan fantasi untuk sebuah cerita. Metode PJBL yang dilakukan siswa dapat membantu siswa dalam berkomunikasi antar siswa untuk membuat sebuah produk menulis dalam meningkatkan keterampilan menulis cerita fantasi pada kelas VII SMP Terpadu Darussalam Depok, metode PBJL berbantuan media Bontang terbukti secara efektif meningkatkan kemampuan menulis teks fantasi.

Hasil analisis yang telah didapatkan bahwasannya nilai peserta didik sudah baik. Peneliti telah melakukan penilaian untuk meningkatkan menulis cerita fantasi pada peserta didik kelas VII-A di SMP Terpadu Darussalam Depok. Berdasarkan analisis data menulis cerita fantasi prasiklus nilai terendah peserta didik yaitu 45, siklus I mengalami peningkatan pada nilai terendah peserta didik yaitu 67,5 dan siklus II mengalami peningkatan hingga nilai terendah peserta didik yaitu 75 . Nilai tertinggi pada prasiklus 75 , Siklus I nilai tertinggi peserta didik mengalami peningkatan yaitu 82,5 dan siklus II nilai peserta didik mengalami peningkatan yaitu 85 . Nilai rata-rata yang dihasilkan di kelas VII-A dapat dilihat dari prasiklus termasuk ke dalam ketegori rendah yaitu 53, siklus I yaitu 73,5 tetapi hanya 12 peserta didik mencapai KKM sehingga peneliti melanjutkan untuk melakukan penelitian tindakan pada siklus II dengan nilai rata-rata 78 dari semua peserta didik yang tuntas dari KKM 70. Peningkatan nilai peserta didik dapat meningkat karena perbaikan pola pembelajaran yang signifikan dapat mempengaruhi kinerja peserta didik dalam belajar. Peningkatan nilai dan nilai ratarata dapat dilihat dari diagram berikut ini.

Gambar 1.3

Diagram Nilai Terendah dan Tertinggi

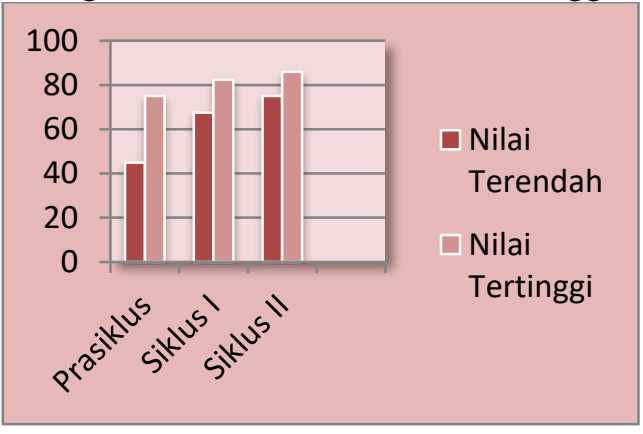

Gambar 1.4

Diagram Hasil Rata-rata Keterampilan Menulis Cerita Fantasi

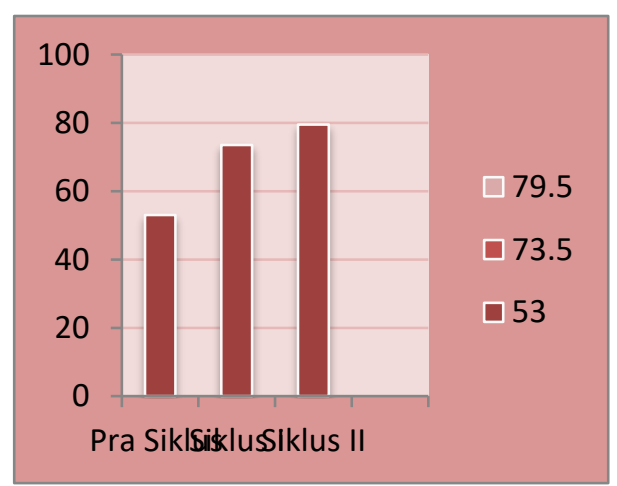

Penilitian ini dapat disimpulkan bahwa pembelajaran yang menggunakan metode pembelajaran berbasis proyek berbantuan media Bontang (boneka tangan) dapat meningkatkan peserta didik dalam menulis cerita fantasi.

\section{DAFTAR PUSTAKA}

Abidin, Zainal. 2020. "Pembelajaran Berbasis Proyek Salah Satu Solusi Kegiatan Belajar Mengajar Di Tengah Pandemi Covid-19" Jurnal Ilmiah Profesi Pendidikan, 5(1). Hal. 65

Dalman. 2014. Menulis Karya Ilmiah. Jakarta: Raja Grafindo Persada.

Fadly, Ahmad. 2020. Peningkatan Menulis Teks Deskripsi dengan Menggunakan 
Film pada SMP 3 Kota Tangerang Selatan. Jurnal Bahasa dan Pengajarannya 3(1). Hal. 305

Helmiati. 2012. Model Pembelajaran. Pekanbaru: Aswaja Pressindo.

Indriyani, Lemi. 2019. "Pemanfaatan Media Pembelajaran Dalam Proses Belajar Untuk Meningkatkan Kemampuan Berpikir Kognitif Siswa" Prosiding Seminar Pendidikan FKIP Universitas Sultasn Agung Tirtayasa 2(1). Hal. 3.

Yanner dkk. 2018. "Pengembangan Bahan Ajar Menulis Teks Cerita Fantasi Bermuatan Nilai Pendidikan Karakter di Kelas VII" Jurnal Pendidikan Teori, Penelitian, dan Pengembangan, 3(1). Hal 101.

Marliana, Lia dkk. 2018. Strategi Belajar Mengajar Bahasa Indonesia. Bandung: P.T Remaja Rosdakarya Offest.

Mukrimaa, Syifa. S. 2014. 53 Metode Belajar dan Pembelajarannya. Bandung: Indonesian University Of Education.

Rehmalemna, Monika. 2015. "Peningkatan Keterampilan Menulis Paragraf Eksposisi Melalui Metode Diskusi Dengan Media Koran Siswa Kelas X SMA Negeri 6 Binjai". Jurnal Edukasi Kultura, 2(2). Hal. 96.

Saddhono, Kundaru. 2012. Meningkatkan Keterampilan Berbahasa Indonesia. Bandung: Karya Putra Darwati.

Soesatyo, Yoyok dkk. 2017. "Pelatihan Penulisan Penelitian Tindakan Kelas (PTK) Bagi Guru Ekonomi Kabupaten Sidoarjo". Jurnal Pemberdayaan Masyarakat Madani (JPMM). 1(2), Hal. 165.

Sulianto, Joko dkk. 2014. "Media Boneka Tangan Dalam Metode Bercerita Untuk Menanamkan Karakter Positif Kepada Siswa Sekola Dasar" Jurnal Pendidikan, 15(1), Hal. 95.

Sudjana dan Rivai. 2019. "Media Pengajaran". Bandung: Sinar Baru Algensindo. 